\title{
Creative Technology in the Curriculum in Online Teacher Training
}

\author{
Danielle E. Kaplan \\ California School of Education, Alliant International University, San Francisco, USA \\ Email:dkaplan@alliant.edu
}

How to cite this paper: Kaplan, D. E. (2017). Creative Technology in the Curriculum in Online Teacher Training. Creative Education, 8, 1223-1235.

https://doi.org/10.4236/ce.2017.88087

Received: February 18, 2017

Accepted: July 7, 2017

Published: July 10, 2017

Copyright (C) 2017 by author and Scientific Research Publishing Inc. This work is licensed under the Creative Commons Attribution International License (CC BY 4.0).

http://creativecommons.org/licenses/by/4.0/

\begin{abstract}
Innovation of and with technology is fundamental to existence. The need for human learning of technology use and possibility is essential. There is a growing and urgent call to enable our population with the skills to access knowledge, interaction and creation capabilities. Including technology in the curriculum is core to advancing thinking about and use of technology, as is incorporating technology instruction into teacher education. Training teachers to facilitate learning about and use of technology in learning is key to reaching students. This research describes the development of online instruction designed to prepare teachers to implement technology use in the classroom.
\end{abstract}

\section{Keywords}

Technology, Education, Teacher Training, Instructional Design

\section{Introduction}

The California School of Education at Alliant International University has included a course in Technology in the Curriculum in a sequence of courses designed for current and future educators to develop today and tomorrow's tinkerers and technology in learning. There were many considerations for how to design the master course of study and mode of study, including accessibility, need, and value. Overarching frameworks are included in the course guiding design, core relevant content, poignant and significant assignments, and meaningful communication. Course learning outcomes include critiquing instructional design of educational technology and evaluation theories and policies in teaching and learning and applying technology design, implementation, and evaluation theories and policies in education. Learning outcomes meet School Conceptual Frameworks and California Department of Education Standards. Regular attendance is expected in consistent participation and submission of course- 
work. A code of ethics includes honesty and responsibility. Accommodations are provided for individuals with disabilities and religious/cultural/spiritual observance.

The overarching objective of this research is to develop the technology skills of all beings by developing the study of technology integration in the training of teachers. A further objective is to develop the online instructional technologies to accomplish this goal. This paper describes the university, school, and state guiding frameworks and the design of the course, including the resources and activities in each module. The university, school, and state frameworks are presented in Section 2. University frameworks include the mission statement and guiding theories and concepts of the university and school, and are in subsections 2.1 through 2.4. State frameworks are in subsection 2.5. The course modules are described in Section 3.

\section{University, School, and State Frameworks Guiding Design (Extracted from Syllabus)}

\subsection{University Mission Statement}

Alliant International University prepares students for professional careers of service and leadership and promotes the discovery and application of knowledge to improve the lives of people in diverse cultures and communities around the world. Alliant is committed to excellence in four areas:

Education for Professional Practice: Alliant's educational programs are designed to give students the knowledge, skills and ethical values they need to serve and lead effectively in a variety of professional settings. Alliant graduates are expected to achieve mastery of a body of knowledge and be able to apply that knowledge in professional practice in order to achieve desired and beneficial outcomes.

Scholarship: Scholarship in the Alliant context includes the discovery of new knowledge; the discovery of new applications of knowledge to solve practical problems; the integration of knowledge in new ways; and innovation in teaching knowledge and professional competencies.

Multicultural and International Competence: Alliant is an inclusive institution committed to serving diverse populations around the world by preparing professionals to work effectively across cultural and national boundaries, by increasing the number of professionals working in underserved areas, and by understanding and responding to the needs of diverse communities.

Community Engagement: Alliant's faculty, students, alumni and staff are dedicated to making a positive difference in the world through professional education and practice. We measure the success of our university in part by the impact we have, both directly and indirectly, on the welfare of individuals, families, organizations and communities.

\subsection{The California School of Education}

Alliant International University offers a full spectrum of credential, certificate 
and degree programs designed to address the educational needs of all learners in the 21st century, from infancy and entry into P-12 education system through adult life. Each program integrates significant, evidence-based, data-driven educational concepts into coursework, focusing on what is successful in education for diverse populations. The California School of Education's mission and vision statements reaffirm our values and commitment to collaboration, diversity, and service to candidates, shared leadership, and the continuous support of the education profession.

Mission: CSOE prepares competent, confident, and conscientious educational leaders who will promote and empower personal growth, academic success, and professional achievement for all in a global society.

Vision: To develop and promote transformative educational experiences that optimize human potential.

Goals: The California School of Education has a set of overarching goals that drive the direction of the School's programs and internal and external operations:

1. To provide the education and training of well-rounded professionals who will serve local, national and global schools and organizations.

2. To engage and partner with communities to translate professional practice and research to meet education needs.

3. To promote an academic culture of support to develop and apply transformative approaches to solve complex societal challenges.

4. To develop analytic skills and sound judgment as applied to content and professional issues.

5. To make warranted and thoughtful decisions about curriculum issues, student-related concerns and leadership that relate to the conduct of the school and the profession.

6. To provide professional educational opportunities for those who aspire to leadership in education settings.

7. To prepare candidates to meet the needs of all learners.

\subsection{Unit Guiding Principles}

CSOE's guiding principles are anchored in the belief that our mission is realized when our candidates are equipped with the skills to operationalize LEAD. LEAD stands for Leadership (L) Engagement (E) Application (A) and Dedication (D). As leaders, candidates demonstrate social responsibility, ethical action, and a commitment to be agents of change to improve the lives of their communities (L). We highlight for our candidates the value of authentic and collaborative engagement in advancing our communities (E). We train our candidates to be reflective professionals who incorporate theory into best practices; and utilize the knowledge, skills, dispositions, habits of inquiry, and technology that their preparation has honed (A). Courses and assignments are intentionally designed to engage experiences that promote the understanding of theories, concepts, principles, methodologies and approaches that candidates can readily utilize for 
practice. As candidates in both initial and advanced stages engage in observations, field experiences, and clinical practice, they provide service to their learners/clients, while simultaneously making instructional decisions that are grounded in educational research and/or theory (D).

L = Leadership: Innovation with Accountability;

E = Engagement: Active Learning;

A = Application: Theory to Practice;

D = Dedication: Inclusive Excellence.

\subsection{School Theoretical Framework}

CSOE is based on two main theoretical frameworks: Boyer's applied scholarship of learning and constructivist theory.

CSOE utilizes Boyer's model of the scholarship of application. Boyer (1990) asserted the need for all disciplines to move beyond traditional research to engage the full scope of academic work. He posits that in order to advance disciplines holistically and to obtain rewards for professional practice, research should encompass four critical areas:

Discovery-generating new and unique knowledge;

Teaching-faculty and candidates creatively build bridges between their own understanding and their students' learning;

Application (later called Engagement) - taking the new knowledge acquired and utilizing to solve society's problems; and

Integration-using collaborative relationships to uncover new knowledge among disciplines (Boyer, 1990).

These four aspects of scholarship are of paramount importance to CSOE. Each of the four areas informs the guiding principles of LEAD for CSOE.

Scholarship of Discovery (L, E, A, D): We subscribe to the centrality of the need to advance inquiry that produces the disciplinary and professional knowledge that frames our candidate preparation and training (Boyer, 1990). We ensure that our candidates are prepared to foster an environment that supports inclusive excellence with the commitment and understanding necessary to be responsive to all learners (D). Candidates acquire the ability to collaborate successfully (E) with parents, families, school districts, community members, faculty and staff in order to gain and maintain this disposition.

Scholarship of Teaching (L, E, A, D): CSOE subscribes to Boyer's model that underscores the notion of the scholarship of teaching as inquiry that produces knowledge to facilitate the transfer of the science and art of teaching, counseling and leadership from expert to novice. Thus we are very intentional in stewarding our mentoring relationships between faculty, school district master teachers, school site supervisors and our advisory boards. We view these relationships as critical to the transfer of teaching knowledge.

Scholarship of Application, Engagement, Professional Practice (A): Professional practice in CSOE is comprised of all aspects of the delivery of education, counseling, and leadership. Competence in practice is determined in school set- 
ting practicums and internships. Professional Practice is also the mechanism through which CSOE provides the environment and skills by which knowledge in the profession is both advanced and applied. In this segment, we also include the mentoring of candidates and leadership roles in developing practice. In all of the above, we highlight the scholarship generated through practice. Our Faculty and candidate professional certifications, degrees, and credentials and other specialty credentials demonstrate CSOE's attainments in this sphere.

Scholarship of Integration (L, E, A): In this sphere, faculty and candidates engage in the review and analysis of education policy, integrative models across disciplines, literature review and use all these to develop transdisciplinary educational programs and projects. Further, CSOE faculty is active and present at national and international conferences, serve on the leadership of professional organizations and contribute to journal articles. These are examples of how CSOE demonstrates the scholarship of integration. The guiding principles and candidate competencies are framed with the understanding that effective learning environments are social and collaborative in nature (Vygotsky, 1978).

The second theoretical underpinning for CSOE is constructivism. We concur with the assertion that our candidates and their students are active makers of meaning, rather than passive absorbers of knowledge (Dewey, 1944; Vygotsky, 1962; Brosio, 2000).

We expect our candidates to engage social constructivism by utilizing existing knowledge, interests, attitudes, and goals to select and interpret available information. Our faculty recognize the insider knowledge our candidates' bring to our courses and provide the environment for them to utilize their uniquely personal knowledge to create meaning as they integrate these knowledge bases with their diverse cultural, ethnic, social, and economic circumstances through analysis, reflection, and research.

We model a humanistic learning environment that encourages critical inquiry to connect learners with one another. Faculty members create caring environments where candidates are encouraged and supported to reach beyond themselves and to engage various points of view, diversity of ideas and practices.

\subsection{Course Learning Outcome Frameworks and Standards}

Course Learning Outcomes meet School Conceptual Frameworks Principles of Leadership, Engagement and Application, CSTP Standards 1 and 2, and TPEs, $1.5,3.3,3.6,3.8$, and 6.5 .

California Standards for the Teaching Profession (CSTP) (from the California Commission on Teacher Credentialing website):

Standard 1: Program Design and Curriculum;

Standard 2: Preparing Candidates to Master the Teaching Performance Expectations (TPEs).

Teaching Performance Expectations (TPEs) (from the California Commission on Teacher Credentialing website).

TPE 3: Understanding and Organizing Subject Matter for Student Learning. 
3.3: Plan, design, implement, and monitor instruction consistent with current subject-specific pedagogy in the content area(s) of instruction, and design and implement disciplinary and cross-disciplinary learning sequences, including integrating the visual and performing arts as applicable to the discipline 1.

3.4: Individually and through consultation and collaboration with other educators and members of the larger school community, plan for effective subject matter instruction and use multiple means of representing, expressing, and engaging students to demonstrate their knowledge.

3.6: Use and adapt resources, standards-aligned instructional materials, and a range of technology, including assistive technology, to facilitate students' equitable access to the curriculum.

3.7: Model and develop digital literacy by using technology to engage students and support their learning, and promote digital citizenship, including respecting copyright law, understanding fair use guidelines and the use of Creative Commons license, and maintaining Internet security.

TPE 4: Planning Instruction and Designing Learning Experiences for All Students.

4.4: Plan, design, implement and monitor instruction, making effective use of instructional time to maximize learning opportunities and provide access to the curriculum for all students by removing barriers and providing access through instructional strategies that include: appropriate use of instructional technology, including assistive technology; applying principles of UDL and MTSS; use of developmentally, linguistically, and culturally appropriate learning activities, instructional materials, and resources for all students, including the full range of English learners; appropriate modifications for students with disabilities in the general education classroom; opportunities for students to support each other in learning; and use of community resources and services as applicable.

\section{Technology in the Curriculum Content and Assignment Modules}

The course is divided into eight weekly modules covering technology in curriculum theories. Each module covers a set of theorists in technology in the classroom and instructional design. Modules include: 1) Blended Learning \& Flipped Classrooms, 2) Technology \& Education Policy, 3) Media Literacy, Learning Theories, Multimedia \& Introduction to Instructional Design, 4) Anchored Instruction, Situated Cognition, \& Goal-based Scenarios, 5) Teaching and Learning by Design, \& Problem and Case based Learning, 6) Games, Simulation, Microworlds \& Programming in Learning, 7) Communities of Practice, Learning Communities, Data Analysis and Visualization, and 8) Technology in Education Evaluation. The modules are made up of resources including links to course content and assignments and communication forums. Resources include readings and applications. Assignments include reviewing and discussing application of theories, creation of artifacts applying theories, and evaluation of artifacts applying theories. Assignment categories include discussion, course project, and 
lesson plans. Additionally, the course includes a Syllabus, Announcements, Course Materials, Discussions, Conferences, Grades, Chat, and a Questions center.

\subsection{Module 1: Blended Learning \& Flipped Classrooms}

Module 1 is an introduction to Blended learning and Flipped classrooms. The goal of the module is to provide an overview of blended and flipped learning. Learning objectives include analyzing the principles of blended and flipped learning and determining how to effectively apply principles of blended and flipped learning. These objectives tie into the School guiding principles of Leadership, Engagement, and Application and California State Standards for the Teaching Profession (CSTP) and Teaching Performance Expectations (TPE) for CSTP Standard 1 Program Design and Curriculum, CSTP Standard 2 Preparing candidates to master the Teaching Performance Expectations, and TPEs 3.3, 3.4, 3.6, 3.7, 3.8, and 4.4.

The module is made up of readings, forums, and assignments. Readings include Edutopia (2007), Johnson \& Mielke (2013), Patrick, Kennedy \& Powell (2013), and flipped classroom and blended learning sites such as Blended Learning Now, INACOL, Knewton, and University of Texas at Austin Learning Sciences. Each reading and site presents guiding and foundational theories of blended and flipped learning. The assignments include designing a lesson plan on a content topic in State Standards to incorporate introductory theories of blended and flipped learning, and share a course project idea and find classmates with complementary ideas and goals to collaborate with on the course project.

\subsection{Module 2: Technology \& Education Policy}

Module 2 is a unit on Technology and Education Policy. The goal of the module is to provide an overview of technology and education policy. Learning objectives include analyzing issues in technology and education policy and determining how to effectively apply the issues in policies, lesson plans and project design. Learning objectives connect to School guiding Principles of Leadership, Application and Engagement, CSTP Standards 1 and 2, TPEs 3.3, 3.4, 3.6, 3.7, 3.8, and 4.4.

The module is made up of readings, forums, and assignments. Readings include Edutopia (2008), Perrott (2011), Worthen \& Patrick (2014), Lakhan \& Khurana (2008), and websites such as the U.S. Department of Education on Science, Technology and Engineering, on the National Education Technology Plan, Privacy Technical Assistance Center, California Education Technology Blueprint, ISTE, AACE, Embrace Civility Digital Citizenship, and Connect Ed Initiative. Each reading presents foundational issues related to technology and education policy such as privacy, intellectual property, training and access. Assignments include brainstorming in project groups over how to incorporate policy issues into project design, researching technology for project, designing an educational technology policy, writing a letter to parents about classroom and school technology and education policy, incorporating policy issues into lesson 
designed in Module 1, and providing meaningful feedback to classmates' lesson and policy designs.

\subsection{Module 3: Media Literacy, Learning Theories, Multimedia, \& Introduction to Instructional Design}

Module 3 is a unit on Media Literacy, Multimedia and Introduction to Learning and Instructional Design Theories. The goal of the module is to provide an overview of media literacy, learning, multimedia, and instructional design theories. Learning objectives include analyzing principles of media literacy, learning, multimedia, and instructional design theories and determining how to effectively apply the media literacy, learning, multimedia, and instructional design theories in lesson plan and project design. Learning objectives connect to School guiding Principles of Leadership, Application and Engagement, CSTP Standards 1 and 2, TPEs 3.3, 3.4, 3.6, 3.7, 3.8, and 4.4.

The module is made up of readings, forums, and assignments. Readings include Calvert \& Kolter (2003), Mayer \& Moreno (2003), Bandura (2001), Palmer (n.d.), Zanetis (2013), Merrill (2002), Black \& McClintock (1995), and websites such as Center for Media Literacy, National Association for Media Literacy Education, Learning Connections and Sesame Workshop. Each reading presents foundational theories in media literacy, learning, multimedia, and instructional design theories. Assignments include brainstorming in project groups over how to incorporate media literacy, learning, multimedia, and instructional design theories into project design, selecting insights from media literacy, learning, multimedia, and instructional design theories and incorporating into lesson designed in Module 1 and 2, and providing meaningful feedback to classmates' lesson designs.

\subsection{Module 4: Anchored Instruction, Situated Cognition, \& Goal-Based Scenarios}

Module 4 is a unit on Anchored Instruction, Situated Cognition \& Goal-based Scenarios. The goal of the module is to provide an overview of Anchored Instruction, Situated Cognition \& Goal-based Scenario theories. Learning objectives include analyzing principles of Anchored Instruction, Situated Cognition \& Goal-based Scenario theories and determining how to effectively apply the principles of Anchored Instruction, Situated Cognition \& Goal-based Scenario theories in lesson plan and project design. Learning objectives connect to School guiding Principles of Leadership, Application and Engagement, CSTP Standards 1 and 2, TPEs 3.3, 3.4, 3.6, 3.7, 3.8, and 4.4.

The module is made up of readings, forums, and assignments. Readings include Crews, Biswas, Bransford, Goldman, Nathan, \& Varma (n.d.), Brown, Collins, \& Duguid (1989), The Cognition and Technology Group at Vanderbilt (1990), and websites such as Engines for Education. Readings present Anchored Instruction, Situated Cognition \& Goal-based Scenario theories. Assignments include brainstorming in project groups over how to incorporate Anchored In- 
struction, Situated Cognition \& Goal-based Scenario theories into project design, create main page of instructional Project website, selecting insights from Anchored Instruction, Situated Cognition \& Goal-based Scenario theories and incorporating into a new lesson with a new content topic in State Standards, and providing meaningful feedback to classmates' lesson designs.

\subsection{Module 5: Teaching and Learning by Design \& Problem and Case Based Learning}

Module 5 is a unit on Teaching and Learning by Design \& Problem and Cased Based Learning. The goal of the module is to provide an overview of Teaching and Learning by Design \& Problem and Cased Based Learning theories. Learning objectives include analyzing principles of Teaching and Learning by Design \& Problem and Cased Based Learning theories and determining how to effectively apply the principles of Teaching and Learning by Design \& Problem and Cased Based Learning theories in lesson plan and project design. Learning objectives connect to School guiding Principles of Leadership, Application and Engagement, CSTP Standards 1 and 2, TPEs 3.3, 3.4, 3.6, 3.7, 3.8, and 4.4.

The module is made up of readings, forums, and assignments. Readings include Leelawong \& Biswas (n.d.), Kolodner, Hmelo, \& Narayanan (n.d.), and Learning by Design articles from the Edutech Institute and College of Computing at Georgia Institute of Technology website. Readings present Teaching and Learning by Design \& Problem and Cased Based Learning theories. Assignments include brainstorming in project groups over how to incorporate Teaching and Learning by Design \& Problem and Cased Based Learning theories into project design, selecting insights from Teaching and Learning by Design \& Problem and Cased Based Learning theories and incorporating into lesson designed in Module 4 , and providing meaningful feedback to classmates' lesson designs.

\subsection{Module 6: Games, Simulation, Microworlds, \& Programming in Education}

Module 6 is a unit on Games, Simulation, Microworlds, \& Programming in Education. The goal of the module is to provide an overview of Games, Simulation, Microworlds, \& Programming in Education theories and applications. Learning objectives include analyzing principles of Games, Simulation, Microworlds, \& Programming in Education theories and applications and determining how to effectively apply the principles of Games, Simulation, Microworlds, \& Programming in Education theories and applications in lesson plan and project design. Learning objectives connect to School guiding Principles of Leadership, Application and Engagement, CSTP Standards 1 and 2, TPEs 3.3, 3.4, 3.6, 3.7, 3.8 , and 4.4 .

The module is made up of readings, forums, and assignments. Readings include Papert (1980), Turkle (1997), Kafai (2006), Sheehy (2011), and websites such as Scratch at MIT Media Lab, Squeakland by Alan Kay and Viewpoints Research, and Second Life by Linden Research. Readings present Games, Simula- 
tion, Microworlds, \& Programming in Education theories and applications. Assignments include brainstorming in project groups over how to incorporate Games, Simulation, Microworlds, \& Programming in Education theories and applications into project design, selecting insights from Games, Simulation, Microworlds, \& Programming in Education theories and applications and incorporating into lesson designed in Module 4, and 5, and providing meaningful feedback to classmates' lesson designs.

\subsection{Module 7: Communities of Practice, Learning Communities, \& Data Analysis and Visualization in Education}

Module 7 is a unit on Communities of Practice, Learning Communities, \& Data Analysis and Visualization in Education. The goal of the module is to provide an overview of Communities of Practice, Learning Communities, \& Data Analysis and Visualization in Education theories and applications. Learning objectives include analyzing principles of Communities of Practice, Learning Communities, \& Data Analysis and Visualization in Education theories and applications and determining how to effectively apply the principles of Communities of Practice, Learning Communities, \& Data Analysis and Visualization in Education theories and applications in lesson plan and project design. Learning objectives connect to School guiding Principles of Leadership, Application and Engagement, CSTP Standards 1 and 2, TPEs 3.3, 3.4, 3.6, 3.7, 3.8, and 4.4.

The module is made up of readings, forums, and assignments. Readings include Swan and Shea (2005), Collins (1987), Bell \& Linn (2000), and websites such as Wenger-Trayner's Communities of Practice, Geospatial revolution from Delaware Department of Education, GIS in K-12 Education from Minnesota Department of Education, National Academies Press Committee on Thinking Spatially, Google Maps, Google for Education, Apply Education, Intel Education, At\&T K-12 Education, Common Sense Education, Wikipedia Education Program, Teaching Channel, Edutopia, and USGS Education. Readings present Communities of Practice, Learning Communities, \& Data Analysis and Visualization in Education theories and applications. Assignments include brainstorming in project groups over how to incorporate Communities of Practice, Learning Communities, \& Data Analysis and Visualization in Education theories and applications into project design, selecting insights from Communities of Practice, Learning Communities, \& Data Analysis and Visualization in Education theories and applications and incorporating into lesson designed in Module 1, 2, and 3 , or 4, 5, and 6, joining and reporting on several learning communities, and providing meaningful feedback to classmates' lesson designs and reporting.

\subsection{Module 8: Technology in Education Evaluation}

Module 8 is a unit on Evaluation of technology design, use and learning. The goal of the module is to provide an overview of evaluation tools for assessment of technology. Learning objectives include analyzing evaluation tools and theories and determining how to effectively apply the principles to lesson plan and 
project evaluation. Learning objectives connect to School guiding Principles of Leadership, Application and Engagement, CSTP Standards 1 and 2, TPEs 3.3, 3.4, 3.6, 3.7, 3.8, and 4.4.

The module is made up of readings, forums, and assignments. Readings include Davies (2011), Assessment and Reporting Unit (2005), Trumbull \& Lash (2013), Noeth, Volkov, \& American College Testing Program (2004), Florida Center for Instructional Technology and other online sites for evaluation and technology evaluation, such as Social Research Methods, Survey Monkey and Rubistar. Readings and websites present evaluation tool for the assessment of technology design and use. Assignments include brainstorming in project groups over how to incorporate evaluation tools into discussing and evaluating classmates' projects.

\section{Meaningful Communication}

Central to development in online instruction is evocative interaction inspiring engaging discussion. Communication includes student to instructor engagement, student to student engagement, and instructor to student engagement. Student to instructor interaction includes submission of assignments and questions. Student to student interaction includes responses to each other's assignment submissions and discussions. Instructor to student engagement occurs in a one to one relationship and a one to many relationships with individual responses to work and group announcements and emails.

\section{Conclusion}

This research is dedicated to improving technology use and advancing knowledge by improving technology abilities and implementation through developing expertise in teachers and students in technology use, design and evaluation in education. The goal was to create a short course, which provides an overview of issues and theories in technology and education and guides participants into integrating issues and theories and State Standards into lessons, policies, and technology creations. Further research will include learning development in the course and instructional and learning progressions in the field from this development.

\section{Acknowledgements}

Acknowledgements to the California School of Education Administrative and Instructional Design teams.

\section{References}

Assessment and Reporting Unit (2005). Current Perspectives on Assessment. Learning Policies Branch, Office of Learning and Teaching: State Government of Victoria. https://www.eduweb.vic.gov.au/edulibrary/public/teachlearn/student/assessment_curre nt_per.pdf

Bell, P., \& Linn, M. (2000). Scientific Arguments as Learning Artifacts: Designing for 
Learning from the Web with KIE. International Journal of Science Education, 22, $797-$ 817. http://www.designbasedresearch.org/reppubs/bell-Linn.pdf https://doi.org/10.1080/095006900412284

Boyer, E. (1990). Scholarship Reconsidered: Priorities for the Professoriate. Princeton, NJ: The Carnegie Foundation for the Advancement of Teaching.

Brosio, G. (2000). Decentralisation in Africa: A Paper Prepared for African Department of the IMF.

Brown, J. S., Collins, A., \& Duguid, P. (1989). Situated Cognition and the Culture of Learning. Educational Research, 18. https://doi.org/10.3102/0013189x018001032 https://www.ideals.illinois.edu/bitstream/handle/2142/17979/ctrstreadtechrepv01989i0 0481_opt.pdf?sequence=1

Calvert, S. L., \& Kotler, J. A. (2003). Lessons from Children's Television: The Impact of the Children's Television Act on Children's Learning. Journal of Applied Developmental Psychology, 24, 275-335. https://doi.org/10.1016/S0193-3973(03)00060-1 http://0-www.sciencedirect.com.library.alliant.edu/science/article/pii/S01933973030006 01

Collins, A. (Chair) (1987). Strategies for Teaching Thinking Skills with Interactive Technologies. Symposium Conducted at the Meeting of the American Educational Research Association, Washington. http://files.eric.ed.gov/fulltext/ED288913.pdf

Crews, T., Biswas, G., Bransford, J., Goldman, S., Nathan, M., \& Varma, S. (n.d.). Adventure Player: Macro Context Plus Micro Worlds. Dept. of Computer Science \& Learning Technology Center: Vanderbilt University, Nashville, Tennessee. http://www.vuse.vanderbilt.edu/ biswas/Research/ile/papers/postscript/aied95.pdf

Davies, R. (2011). Understanding Technology Literacy: A Framework for Evaluating Educational Technology Integration. Techtrends: Linking Research \& Practice to Improve Learning, 55, 45-52. https://doi.org/10.1007/s11528-011-0527-3 http://0-search.ebscohost.com.library.alliant.edu/login.aspx?direct $=$ true $\& \mathrm{db}=\mathrm{ehh} \& \mathrm{AN}$ $=64128323 \&$ site $=$ ehost-live $\&$ scope $=$ site

Dewey, J. (1944). Democracy and Education. New York, NY: The Free Press.

Edutopia (2008). Results of a Survey of America's Teachers and Support Professionals in Technology in Public Schools and Classrooms. American Federation of Teachers, National Education Association. http://www.edutopia.org/pdfs/NEA-Access,Adequacy,andEquityinEdTech.pdf

Kafai, Y. B. (2006). Playing and Making Games for Learning: Instructionist and Constructionist Perspectives for Game Studies. Games and Culture, 1, 36-40. http://0-gac.sagepub.com.library.alliant.edu/content/1/1/36.full.pdf + html https://doi.org/10.1177/1555412005281767

Kolodner, J. L., Hmelo, C. E., \& Narayanan, N. H. (n.d.). Problem-Based Learning Meets Case-Based Reasoning. The EduTech Institute College of Computing, Georgia Institute of Technology. http://www.cc.gatech.edu/projects/lbd/pdfs/pblcbr.pdf

Lakhan, S., \& Khurana, M. (2008). Intellectual Property, Copyright, and Fair Use in Education. Academic Leadership, 6, 1.

http://0-search.ebscohost.com.library.alliant.edu/login.aspx?direct=true\&db=ehh\&AN $=43153292 \&$ site $=$ ehost-live $\&$ scope $=$ site

Leelawong, K., \& Biswas, G. (n.d.). Designing Learning by Teaching Agents: The Betty's Brain System. Department of EECS/ISIS, Vanderbilt University. http://teachableagents.org/papers/2008/Leelawong-DesigningLearningbyTeachingAge nts(2008).pdf

Mayer, R. E., \& Moreno, R. (2003). Nine Ways to Reduce Cognitive Load in Multimedia Learning. Educational Psychologist, 38, 43-52. 
http://0-search.ebscohost.com.library.alliant.edu/login.aspx?direct=true\&db=aph\&AN $=9110440 \&$ site $=$ ehost-live $\&$ scope $=$ site https://doi.org/10.1207/S15326985EP3801_6

Noeth, R. J., Volkov, B. B., \& American Coll. Testing Program (2004). Evaluating the Effectiveness of Technology in Our Schools. ACT Policy Report. American College Testing ACT Inc. http://files.eric.ed.gov/fulltext/ED483855.pdf

Palmer (n.d). Television for Learning: Our Foremost Tool in the 21st Century. Opinion Article 7, Learning without Frontiers, UNESCO. http://www.unesco.org/education/lwf/doc/portfolio/opinion7.htm

Perrott, E. (2011). Copyright in the Classroom: Why Comprehensive Copyright Education Is Necessary in United States K-12 Education Curriculum. Intellectual Property Brief, 2, 5-18.

http://digitalcommons.wcl.american.edu/cgi/viewcontent.cgi?article=1058\&context=ip brief

Sheehy, K. (2011). High School Teachers Make Gaming Academic. U.S. News and World Report.

http://www.usnews.com/education/high-schools/articles/2011/11/01/high-school-teach ers-make-gaming-academic?int $=96 \mathrm{e} 908$

Swan, K., \& Shea, P. (2005). The Development of Virtual Learning Communities. In. S. R. Hiltz, \& R. Goldman (Eds.), Asynchronous Learning Networks: The Research Frontier (pp. 239-260). New York, NY: Hampton Press.

http://www.rcet.org/research/publications/chapter_11.pdf

The Cognition and Technology Group at Vanderbilt (1990). Anchored Instruction and Relationship to Situated Cognition. Educational Researcher, 19, 2-10. http://0-edr.sagepub.com.library.alliant.edu/content/19/6/2.full.pdf https://doi.org/10.3102/0013189X019006002

Trumbull, E., \& Lash, A. (2013). Understanding Formative Assessment: Insights from Learning Theory and Measurement Theory. https://www.wested.org/online_pubs/resource1307.pdf

Turkle, S. (1997). Seeing through Computers (pp. 76-82). The American Prospect. http://0-search.proquest.com.library.alliant.edu/docview/201056631 ?accountid $=25255$

Vygotsky, L. S. (1962). Thought and Language. Cambridge, MA: MIT Press. https://doi.org/10.1037/11193-000

Vygotsky, L. S. (1978). Mind in Society. Cambridge, MA: Harvard University Press.

Worthen, M., \& Patrick, S. (2014). The iNACOL State Policy Frameworks: 5 Critical Issues to Transform K-12 Education. iNACOL, The International Association for K-12 Online Learning.

http://www.inacol.org/wp-content/uploads/2015/03/iNACOL-State-Policy-Framework s-5-Critical-Issues-to-Transform-K12-Education-Nov2014.pdf

Zanetis, J. (2013). Video Conferencing Deserves a Second Look. Education World. http://www.educationworld.com/a_issues/chat/chat127-2.shtml 
Submit or recommend next manuscript to SCIRP and we will provide best service for you:

Accepting pre-submission inquiries through Email, Facebook, LinkedIn, Twitter, etc. A wide selection of journals (inclusive of 9 subjects, more than 200 journals)

Providing 24-hour high-quality service

User-friendly online submission system

Fair and swift peer-review system

Efficient typesetting and proofreading procedure

Display of the result of downloads and visits, as well as the number of cited articles Maximum dissemination of your research work

Submit your manuscript at: http://papersubmission.scirp.org/

Or contact ce@scirp.org 